Li et al., Afr J Tradit Complement Altern Med., (2017) 14 (4): 213-220

https://doi.org/10.21010/ajtcam.v14i4.24

\title{
ANTICANCER ACTIVITY OF 5, 7-DIMETHOXYFLAVONE AGAINST LIVER CANCER CELL LINE HEPG2 INVOLVES APOPTOSIS, ROS GENERATION AND CELL CYCLE ARREST
}

\author{
Hengping Li ${ }^{1}$, Xiaolei Zhang ${ }^{2}$, Weixing Wang ${ }^{1 *}$
}

${ }^{1}$ Deaprtment of general surgery, Renmin Hospital of Wuhan university (Hubei General hospital), Wuhan 430060, China., ${ }^{2}$ Deaprtment of pain treatment, the first people's hospital of xiangyang, xiangyang 441000 , China.

*Corresponding author Email: weixingwang34@ hotmail.com

\begin{abstract}
Background: Flavonoids are considered potential anticancer agents owing to their properties to interact with a diversity of cellular entities. Among flavonoids, methylated flavones are more efficient anticancer agents due to their higher stability in vivo. The purpose of the present study was, therefore, to evaluate the anticancer effect of methylated natural flavonoid 5, 7dimethoxyflavone (5, 7-DMF)

Materials and methods: MTT assay was used to determine the anticancer activity and $\mathrm{IC}_{50}$ of 5, -DMF). Cell viability, cell cycle distribution, reactive oxygen species (ROS) and mitochondrial membrane potential $(\triangle \Psi m)$ were carried out by flow cytometry. Apoptosis was studied by DAPI staining.

Results: MTT assay revealed that the molecule reduced the cell viability of HepG2 cancer cells. The $\mathrm{IC}_{50}$ of 5, 7-DMF was found to be $25 \mu \mathrm{M}$. Our result indicated that 5, 7-DMF triggered production of ROS and significantly reduced $\Delta \Psi_{m}$. It also leads to arrest of HepG2 cells in Sub-G1 stage of cell cycle, and ultimately induced apoptosis in a concentration-dependent manner, as indicated by DAPI staging. Additionally, 5, 7-DMF also reduced the colony forming potential of the HepG2 cells concentration dependently.

Conclusion: Taken together, we conclude that 5, 7-DMF induces cell death via ROS generation, cell cycle arrest and apoptosis, and, therefore, may prove beneficial in the treatment of liver cancer.
\end{abstract}

Key words: Apoptosis, reactive oxygen species, mitochondrial membrane potential, 5, 7-dimethoxyflavone, Liver cancer

\section{Introduction}

Liver cancer is considered as one of the most widespread malignancies across the globe. According to a recent estimate, about 782,000 people were diagnosed for liver cancer, out of which 746,000 people died (Ferlay et al., 2015). Moreover, lung cancer accounts for about $5.6 \%$ of all new cancer cases diagnosed every year, and approximately $9.1 \%$ of all cancer related deaths across the globe (Ferlay et al., 2015). The sharp increase in the incidence of liver cancer, lack of proper cure and the severe side-effects associated with the synthetic drugs has made it necessary to search for new and more effective molecules. In the past few decades, across the globe there has been a budding interest in the use of herbal drugs or herb-derived natural products, due to their lower side effects. Among the natural products, flavonoids form a large group of compounds ubiquitously found across plant kingdom. (Marder et al., 1998). These molecules have been reported to possess tremendous pharmacological properties, which include antimicrobial, antioxidant and anticancer activities (Nagaoka et al., 2002). The bioactivities of flavonoids are attributed to their ability to interact with a diversity of cellular enzymes. Moreover, flavonoids act as scavengers of reactive oxygen species (ROS), and also avert their formation by chelating metals (Alsono et al., 1996, Takagaki et al., 2005). The use of flavonoids as prospective chemopreventive agents has gained interest in the recent past. Nonetheless, their stability and bioavailability are considered as a cause for concern that limits their use. Recent studies revealed that the methylated flavones have the benefit of increased metabolic stability, and may prove to be more beneficial as chemopreventive agents. One such molecule is the naturally-occurring 5, 7dimethoxyflavone (5,7-DMF), which has been shown to exhibit considerable anticancer activity against human cancers originating from mouth, esophagus and lung (Petra et al., 2006). It has been reported that 5, 7-DMF is 10 times more potent inhibitor of cell proliferation than its unmethylated analogs of chrysin. Interestingly, 5, 7-DMF inhibited the proliferation of 
Li et al., Afr J Tradit Complement Altern Med., (2017) 14 (4): 213-220

https://doi.org/10.21010/ajtcam.v14i4.24

the cancer cell lines, including oral squamous cell carcinoma SCC-9 cells and breast cancer MCF-7 cells. However, it exhibited very little effect on two immortalized normal cell lines (Walle et al., 2007, Eom et al., 2010).

Additionally, 5, 7-DMF is present in several edible plants, such as piper (Patanasethanont et al., 2007) and other plant sources and is, therefore, likely to exhibit minimal toxicity in humans. Against this backdrop, the present study was designed to examine the anticancer activity of 5, 7-DMF against liver cancer cell line HepG2, and explore the possible underlying mechanism. Our results indicated that 5, 7-DMF exhibits significant anticancer activity against liver cell line HepG2 through ROS induced apoptosis and cell cycle arrest, and, therefore, may prove beneficial in the management of liver cancer.

\section{Materials and methods \\ Chemicals and Reagents}

5, 7-dimethoxyflavone and dimethyl and sulfoxide (DMSO), were obtained from Sigma-Aldrich Co. (St. Louis, MO, USA). All primary and secondary antibodies were purchased from Santa Cruz Biotechnology Inc. (Santa Cruz, CA, USA). The fluorescent probes DCFH-DA, 4'-6-diamidino-2-phenylindole (DAPI), Fetal bovine serum (FBS), RPMI-1640 medium, L-glutamine, antibiotics were obtained from Invitrogen Life Technologies (Carlsbad, CA, USA) were obtained from Invitrogen Life Technologies.

\section{Cell culture}

The liver cancer cell line HepG2 was procured from the Food Industry Research and Development Institute (Hsinchu, Taiwan) and preserved in RPMI-1640 medium tissue culture flasks at $37{ }^{\circ} \mathrm{C}$ under a humidified $5 \% \mathrm{CO}_{2}$ and 95 $\%$ air.

\section{Evaluation of cytoxicity of 5, 7-DMF against HepG2}

The anticancer effect of 5, 7-DMF was determined against liver cancer cell line HepG2 using MTT assay. The cytotoxic effect of 5, 7-DMF against HepG2 was expressed as $\mathrm{IC}_{50}$.

\section{Assessment of viability of HepG2 cells}

Cancer HepG2 cells were seeded at the density of $2 \times 10^{5}$ cells/well were plated on into 6 well plates and treated with 5, 7-DMF for $48 \mathrm{~h}$ and treated with 10,25 and $50 \mu \mathrm{M} \mathrm{5,7-DMF}$ or only with vehicle (DMSO, $1 \%$ in culture media). Afterwards, cell viability was estimated from each treatment by PI exclusion method and flow cytometry as reported previously (Hsu et al., 2007).

\section{Estimation of cell cycle distribution of HepG2 cells}

The cells were seeded in 6 well plates at a density of $2 \times 10^{5}$ cells/well and flavonoid 5, 7-dimethoxyflavone was administrated to the cells at the concentrations of $0,10,25$ and $50 \mu \mathrm{M}$ followed by $24 \mathrm{~h}$ of incubation. DMSO was used as a control. For estimation of DNA content, PBS was used to wash the cells and fixed in ethanol at $-20^{\circ} \mathrm{C}$. This was followed by re-suspension in PBS holding $40 \mu \mathrm{g} / \mathrm{ml}$ PI and, RNase A $(0.1 \mathrm{mg} / \mathrm{ml})$ and Triton X-100 $(0.1 \%)$ for $30 \mathrm{~min}$ in a dark room at $37^{\circ} \mathrm{C}$. Afterwards, analysis was carried out by flow cytometry as reported previously (Hsu et al., 2007).

\section{Evaluation of reactive oxygen species (ROS) and mitochondrial membrane potential $\left(\Delta \Psi_{m}\right)$}

HepG2 cells were seeded at a density of $2 \times 10^{5}$ cells/well in a 6 well plate and kept for $24 \mathrm{~h}$ and treated with $25 \mu \mathrm{M}$ 5, 7-DMF for 6-72 h at $37^{\circ} \mathrm{C}$ in $5 \% \mathrm{CO}_{2}$ and $95 \%$ air. Thereafter cells from all treatment were collected, washed 2 times by PBS and re-suspended in $500 \mu \mathrm{l}$ of DCFH-DA $(10 \mu \mathrm{M})$ for ROS estimation and $\mathrm{DiOC}_{6}(1 \mu \mathrm{mol} / \mathrm{l})$ for $\Delta \Psi_{\mathrm{m}}$ at $37{ }^{\circ} \mathrm{C}$ in dark room for $30 \mathrm{~min}$. The samples were then analyzed instantly using flow cytometry as reported previously (Chiang et al., 2011). 
Li et al., Afr J Tradit Complement Altern Med., (2017) 14 (4): 213-220

https://doi.org/10.21010/ajtcam.v14i4.24

\section{DAPI staining}

HepG2 cells were seeded in 6-well plates at a density of $2 \times 10^{5}$ cells/well and administrated with 10 to $50 \mu \mathrm{M}$ for $48 \mathrm{~h}$. The cells were then stained by DAPI. Afterwards, the samples were studied and photographs were taken under fluorescence microscopy as previously reported (Haun et al., 2006).

\section{Results}

\section{5, 7-DMF induced decreased viability of HepG2 liver cancer cell line}

5, 7-DMF was evaluated against HepG2 cell line and was found to exhibit an $\mathrm{IC}_{50}$ of $25 \mu \mathrm{M}$. After administration of several doses of 5, 7-DMF for different time intervals, cell viability was determined. It was observed that 5, 7-DMF decreased the percent viability of cells concentration as well as time-dependently (Fig. 1a-b).
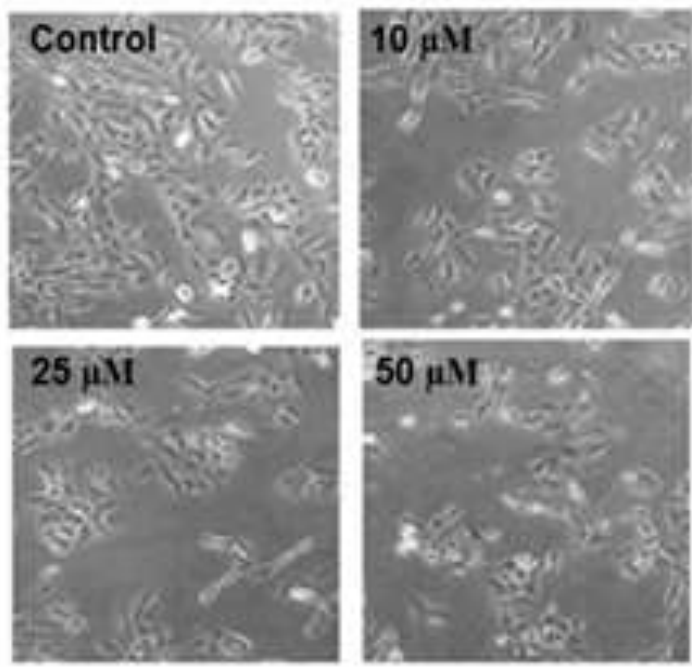

(a)

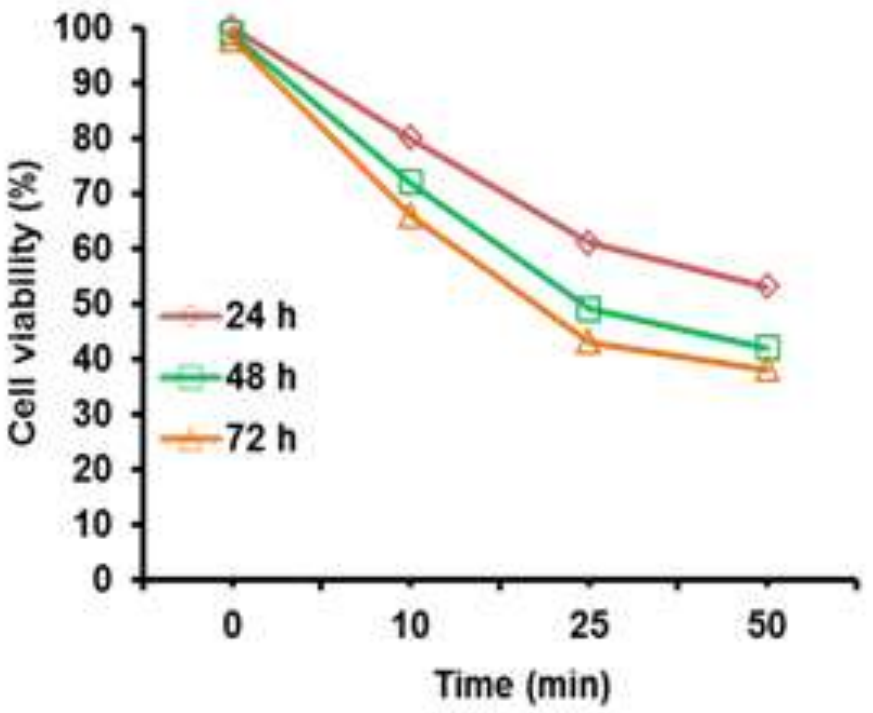

(b)

Figure 1: 5, 7-DMF induced alterations in (a) cell morphology and (b) percent cell viablility. HepG2 cells were administrated with 10, 25 and 50, $\mu \mathrm{M}$ of Caffeic acid n-butyl ester for 24, 48 or $72 \mathrm{~h}$. Each value is mean of three replicates \pm S.D.

\section{5, 7-DMF caused alterations in cell cycle distribution of HepG2 cancer cell lines}

It was observed that the percentage of HepG2 cells was considerably increased in G1 at the concentrations of 0 to $50 \mu \mathrm{M}$ concentrations of 5, 7-DMF causing G1 arrest (Fig. 2). Additionally, the populations of HepG2 cells in sub-G1 phase were marginally increased at a dose of $10 \mu \mathrm{M}$, reasonably increased at $25 \mu \mathrm{M}$, and dramatically increased at $50 \mu \mathrm{M}$. Thus, 5, 7-DMF induced sub-G1 increase of HepG2 cancer cells in a dose-dependent pattern. 
Li et al., Afr J Tradit Complement Altern Med., (2017) 14 (4): 213-220

https://doi.org/10.21010/ajtcam.v14i4.24
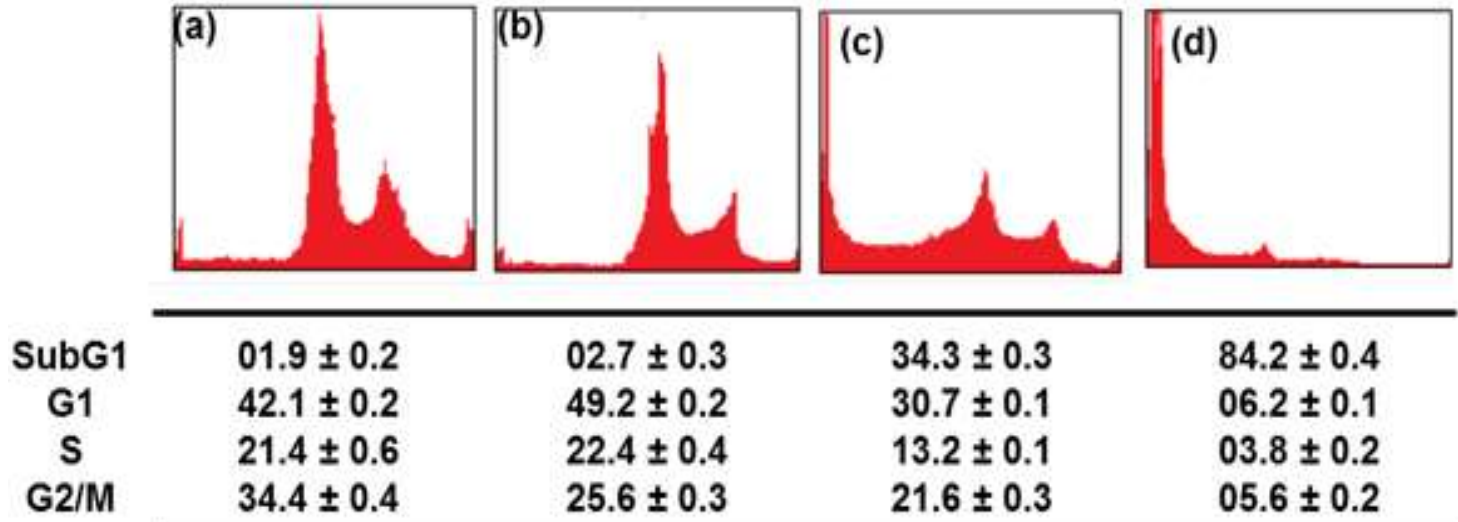

$01.9 \pm 0.2$
$42.1 \pm 0.2$
$21.4 \pm 0.6$
$34.4 \pm 0.4$

$$
\begin{aligned}
& 02.7 \pm 0.3 \\
& 49.2 \pm 0.2 \\
& 22.4 \pm 0.4 \\
& 25.6 \pm 0.3
\end{aligned}
$$$$
34.3 \pm 0.3
$$$$
30.7 \pm 0.1
$$

$13.2 \pm 0.1$

$84.2 \pm 0.4$

$06.2 \pm 0.1$

$21.6 \pm 0.3$

Figure 2: Cell cycle distribution of HepG2 cells at 0, 10, 25, 50 $\mu \mathrm{M}$ of 5, 7-DMF. Results are mean of three biological replicates and expressed as mean $\pm \mathrm{SD}$

\section{5, 7-DMF augmented the accretion of ROS reduced the $\Delta \Psi_{m}$ level}

HepG2 cells were administrated with $25 \mu \mathrm{M}$ 5, 7-DMF for various time intervals and ROS and $\Delta \Psi_{m}$ levels were evaluated. A considerable upsurge in intracellular ROS (Fig. 3) and a significant reduction of $\Delta \Psi_{m}$ level were experienced in the 5, 7-DMF treated HepG2 cells as compared to the control. It was observed that 5, 7-DMF treatment considerably augmented the ROS levels from $12 \mathrm{~h}$ to $72 \mathrm{~h}$ than the control. Furthermore, 5, 7-DMF considerably reduced $\Delta \Psi_{\mathrm{m}}$ level around $37 \%$ in $48 \mathrm{~h}$ administration in HepG2 cells as compared to control (Fig. 4).

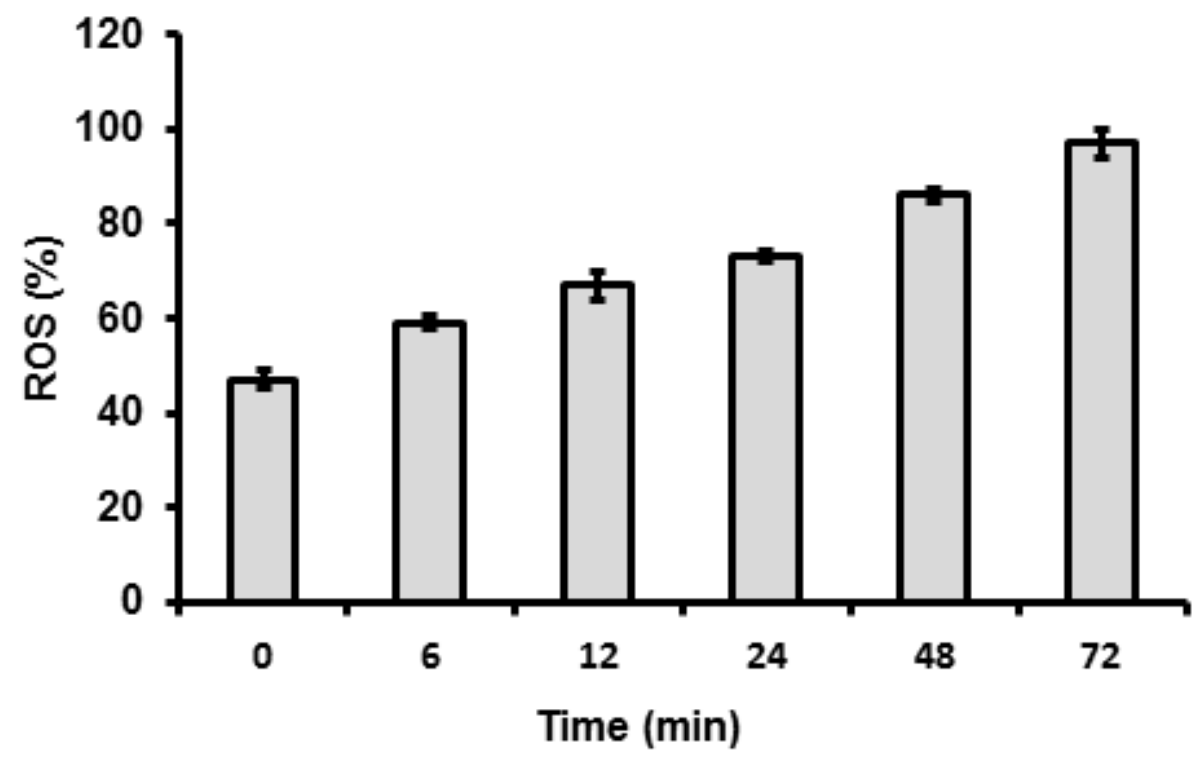

Figure 3: Determination of ROS at $0,125 \mu \mathrm{M}$ of 5, 7-DMF at indicated time intervals. Results are mean of three biological replicates and expressed as mean $\pm \mathrm{SD}$. 
Li et al., Afr J Tradit Complement Altern Med., (2017) 14 (4): 213-220

https://doi.org/10.21010/ajtcam.v14i4.24
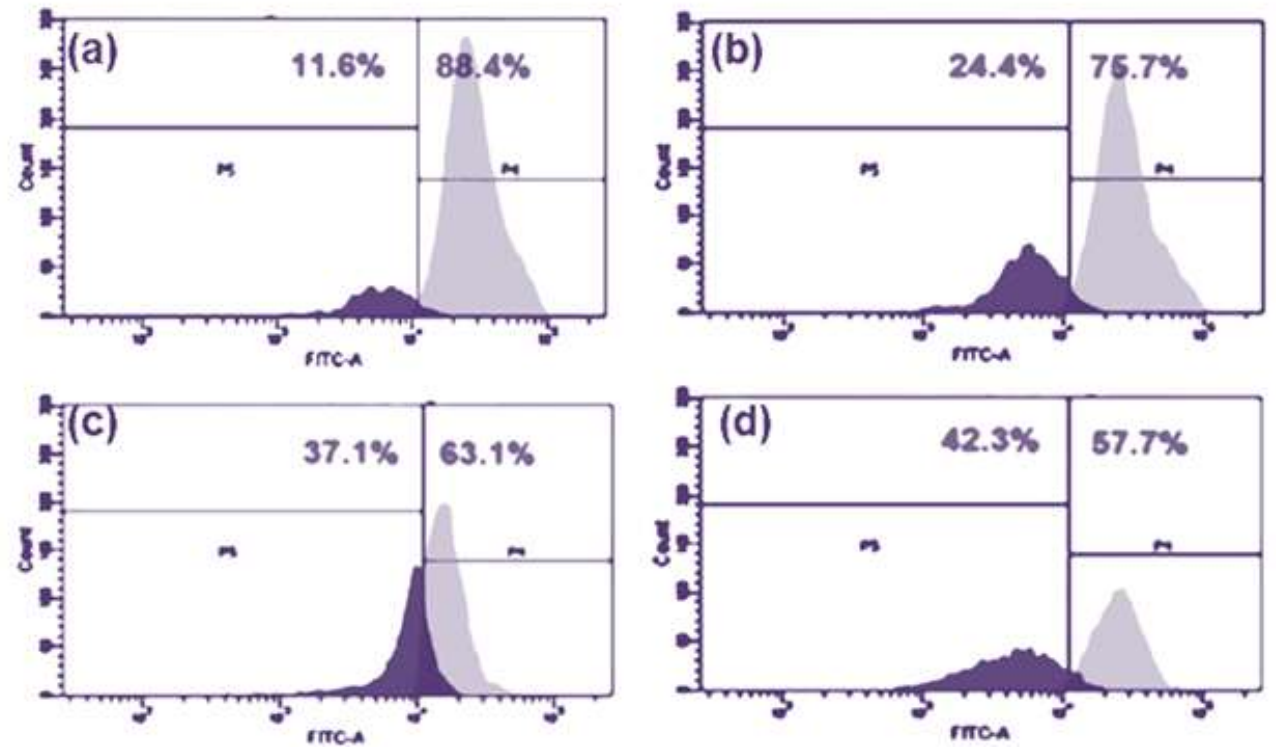

Figure 4: Evaluation of MMP by flow cytometry at (a) 0 h (b) 12 (c) 24 (d) 48 at $25 \mu \mathrm{M}$ of 5, 7-DMF. Results are mean of three biological replicates and expressed as mean \pm SD

\section{5, 7-DMF induced apoptosis in HepG2 cells}

DAPI staining indicated that 5, 7-DMF -administrated cells showed condensed and marked fragmented nuclei in a concentration dependent manner. At $25 \mu \mathrm{M}$ most of the cells go through apoptosis; and the increase of the apoptotic corps was noted (Fig. 5). The total number of viable cells that form colonies were also determined at different concentrations and results showed that 5, 7-DMF reduced the percentage of colony formation dose-dependently (Fig. 6).
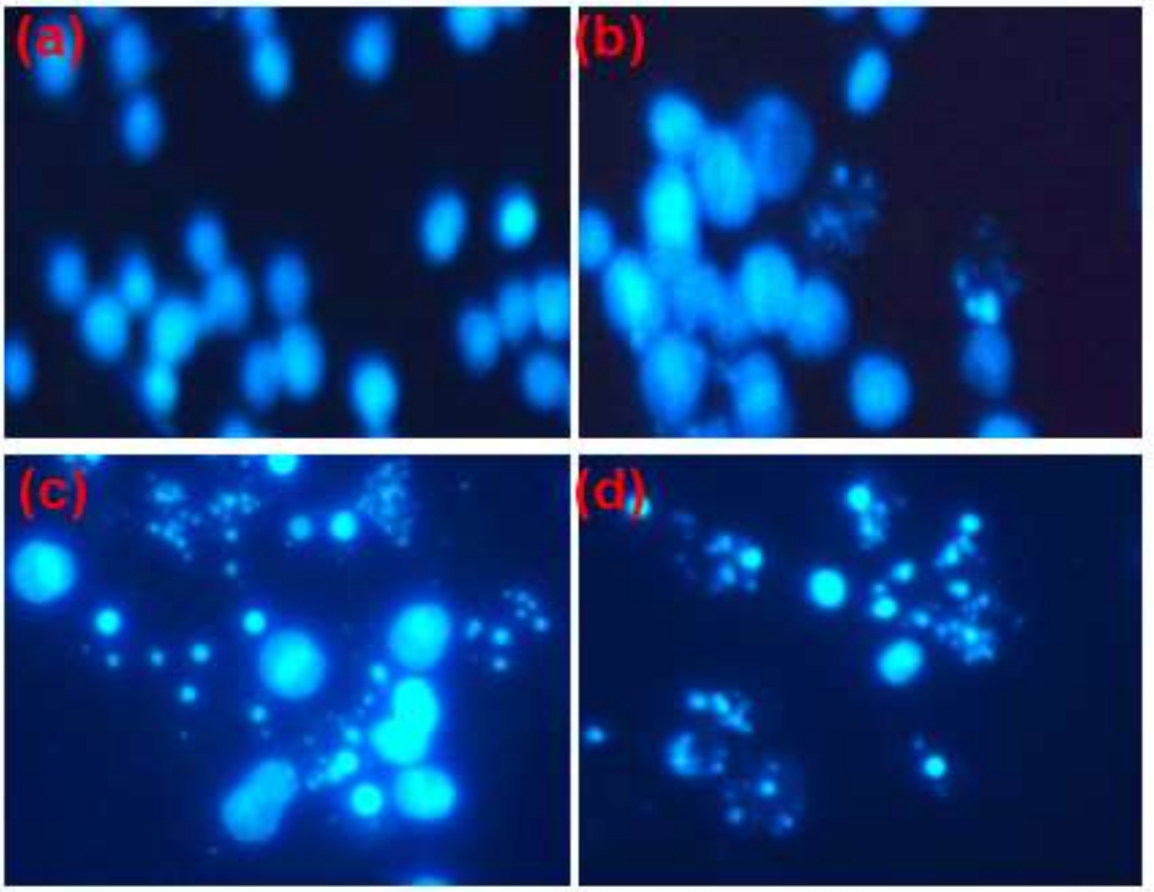

Figure 5: Induction of apoptosis at as evident from DAPI staining (a) 0 (b) $10 \mu \mathrm{M}$ (c) $25 \mu \mathrm{M}$ and (d) $50 \mu \mathrm{M}$ of 5, 7-DMF. Results are representatives of three biological replicates. 
Li et al., Afr J Tradit Complement Altern Med., (2017) 14 (4): 213-220

https://doi.org/10.21010/ajtcam.v14i4.24

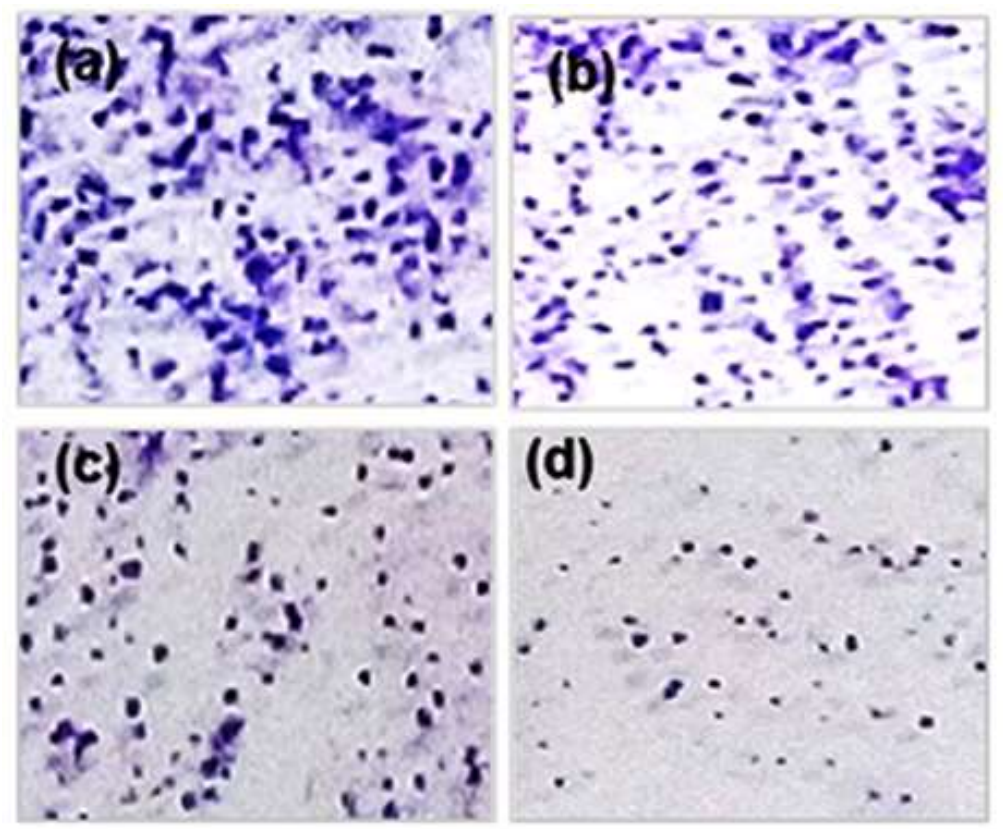

Figure 6: Colony forming potential of HepG2 cells at (a) 0 (b) $10 \mu \mathrm{M}$ (c) $25 \mu \mathrm{M}$ and (d) $50 \mu \mathrm{M}$ of 5, 7-DMF. Results are representatives of three biological replicates.

\section{Discussion}

Liver cancer is considered as one of the most prevalent malignant tumors across the globe. It accounts for about $5.6 \%$ of all new cancer cases diagnosed every year and approximately $9.1 \%$ of all cancer related deaths across the globe (Ferlay et al., 2012). The sharp increase in the incidence of liver cancer, lack of proper cure and the severe side-effects associated with the synthetic drugs, has made it necessary to search for new and more effective molecules. Since natural flavonoids have minimum toxicity associated with them, they are being considered as potential anticancer agents. In the present study, 5, 7-DMF, a natural flavonoid, was evaluated against liver cancer cell line HepG2 for its potential anticancer activity.

Results indicated that the molecule exhibits significant anticancer activity against $\mathrm{HepG} 2$ cell line with an $\mathrm{IC}_{50}$ of 25 $\mu$ M. 5, 7-DMF exhibited the potential to cause cell cycle arrest as it induced the sub-G1 increase of HepG2 cancer cells in a dose-dependent pattern (Fig. 2). Cell cycle checkpoints are important control mechanisms that ensure the proper execution of cell cycle events. Many drugs have been reported to exert their effects through cell cycle and ultimately cause cell death (Vermund and Gollin, 1968). To gain indepth understanding about the underlying mechanism for anticancer activity of 5, 7-DMF, we examined if 5, 7-DMF could induce generation of ROS in HepG2 cancer cells. ROS are generated in and around mitochondria role in the induction of apoptosis (Vermund et al., 1968). For instance, capsaicin disrupts $\Delta \Psi_{m}$ and mediates oxidative stress resulting in apoptosis in pancreatic cancer cells (Sun et al., 2004). The results indicated that 5, 7DMF significantly enhanced the production of ROS and decreased the $\Delta \Psi_{m}$ in HepG2 cancer cells in a dose-response manner (Fig. 3-4), providing a strong clue towards the role of ROS mediated $\Delta \Psi \mathrm{m}$ alteration in cell death. Our results are information with previous studies wherein flavonoids such as 5,7-DMF have been reported to generate reactive oxygen intermediates in cancer cells. The accumulation of intercellular ROS leads to the disruption of the mitochondrial membrane potential, the release of cyctochrome $\mathrm{c}$ into the cytosol with subsequent activation of the caspase cascade, and ultimately leading to apoptosis (Zou et al., 2004, Staib et al., 2003, Yang et al., 2012). Moreover, several genotoxic drugs exert their cytotoxic effects via DNA damage causing cell death (Vermund and gollin, 1968) Hence, a number of chemopreventive agents aim at apoptosis-inducing pathways (Sun et al., 2004). For instance, several anticancer drugs, such as cisplatin (Azuma et al., 2003), 5-fluorourcil (Yoneda et al., 1998), and taxol (Abal et al., 2003), have been reported to induce specific apoptotic pathways. Additionally, resistance to drug is partly explained by the ability of cancer cells to escape apoptosis (Ferreria et al., 2004, Malaguarnera, 2004, Luqmani, 2005). Further, drugs with apoptosis-triggering properties may minimise potential drug resistance. Our results indicated that cells treated with 5, 7-DMF induced apoptosis in vitro in a dose dependent manner as was evident from DAPI staining (Fig. 5). Moreover, it also reduced colony forming tendency of the HepG2 cells (Fig 6). The results suggest that 5, 7-DMF may trigger apoptosis through increasing intracellular ROS. 


\section{Li et al., Afr J Tradit Complement Altern Med., (2017) 14 (4): 213-220 \\ https://doi.org/10.21010/ajtcam.v14i4.24}

Our results are in agreement with previous studies wherein many anti-cancer drugs or herbal extracts target cancer cells partly by inducing apoptosis through creation of high levels of intracellular ROS (Joeng et al., 2010, Simon et al., 2000, Kowaltowski et al., 2009).

\section{Conclusion}

Taken together, we conclude that 5, 7-DMF exhibits considerable anticancer activity against liver cancer cell line HepG2. The anticancer activity may be due to its capacity to induce alterations in intercellular ROS, $\Delta \Psi_{m}$ and cell cycle arrest, which ultimately culminates in apoptosis. The present study paves way for in vivo evaluation of natural molecules against liver cancer.

\section{References}

1. Abal, M., Andreu, J.M., Barasoain, I., (2003). Taxanes: microtubule and centrosome targets, and cell cycle dependent mechanisms of action. Curr. Cancer Drug Targets, 3:193-203.

2. Alonso, D. F., Farías, E. F., Urtreger, A., Ladeda, V., Vidal, M. D. C. C., \& Bal De Kier Joffe, E. (1996). Characterization of F3II, a sarcomatoid mammary carcinoma cell line originated from a clonal subpopulation of a mouse adenocarcinoma. J. Sr Oncol. 62: 288-297.

3. Azuma, M., Tamatani, T., Ashida, Y., Takashima, R., Harada, K., Sato, M., (2003). Cisplatin induces apoptosis in oral squamous carcinoma cells by the mitochondria-mediated but not the NF-kappaB-suppressed pathway. Oral Oncol. 39:282-289.

4. Chiang, J. H., Yang, J. S., Ma, C. Y., Yang, M. D., Huang, H. Y., Hsia, T. C., and Chung, J. G. (2010). Danthron, an anthraquinone derivative, induces DNA damage and caspase cascades-mediated apoptosis in SNU-1 human gastric cancer cells through mitochondrial permeability transition pores and Bax-triggered pathways. Chem. Res. Toxicol. 24: 20-29.

5. Chiang, L. C., Ng, L. T., Lin, I. C., Kuo, P. L., and Lin, C. C. (2006). Anti-proliferative effect of apigenin and its apoptotic induction in human Hep G2 cells. Cancer lett. 237: 207-214.

6. Eom, K.S., Kim, H.J., So, H.S., Park, R., Kim, T.Y (2010). Berberine induced apoptosis in human glioblastoma T98G cells is mediated by endoplasmic reticulum stress accompanying reactive oxygen species and mitochondrial dysfunction. Biol Pharm Bull. 33:1644-1649

7. Ferlay, J., Soerjomataram, I., Dikshit, R., Eser, S., Mathers, C., Rebelo, M., Parkin, D.M., Forman, D. and Bray, F., (2015). Cancer incidence and mortality worldwide: sources, methods and major patterns in GLOBOCAN 2012. Inter. J. Cancer. 136: E359-E386.

8. Ferreira, C.G., Epping, M., Kruyt, F.A., Giaccone, G., (2004). Apoptosis: target of cancer therapy. Clin. Cancer Res. 2002, 8:2024-2034. 43.

9. Hsu, S. C., Kuo, C. L., Lin, J. P., Lee, J. H., Lin, C. C., Su, C. C., and Chung, J. G. (2007). Crude extracts of Euchresta formosana radix induce cytotoxicity and apoptosis in human hepatocellular carcinoma cell line (Hep3B). Anticancer Res. 27: 2415-2425.

10. Huan, S. K. H., Lee, H. H., Liu, D. Z., Wu, C. C., and Wang, C. C. (2006). Cantharidin-induced cytotoxicity and cyclooxygenase 2 expression in human bladder carcinoma cell line. Toxicol. 223: 136-143.

11. Jeong, J.C., Jang, S.W., Kim, T.H., Kwon, C.H., Kim, Y.K., (2010). Mulberry fruit (Moris fructus) extracts induce human glioma cell death in vitro through ROS dependent mitochondrial pathway and inhibits glioma tumor growth in vivo. Nutr. Cancer 6:402-412.

12. Kowaltowski, A.J., de Souza-Pinto, N.C., Castilho, R.F., Vercesi, A.E., (2009). Mitochondria and reactive oxygen species. Free Radic Biol. Med. 47:333-343.

13. Luqmani, Y.A., (2005). Mechanisms of drug resistance in cancer chemotherapy. Med. Princ. Pract. 14:35-48.

14. Malaguarnera L: Implications of apoptosis regulators in tumorigenesis. (2004). Cancer Metastasis Rev. 23:367-387.

15. Marder, M., Viola, H., Bacigaluppo, J. A., Colombo, M. I., Wasowski, C., Wolfman, C., and Paladini, A. C. (1998). Detection of benzodiazepine receptor ligands in small libraries of flavone derivatives synthesized by solution phase combinatorial chemistry. Biochem. biophy. Res. Comm. 249: 481-485.

16. Nagaoka, T., Banskota, A. H., Tezuka, Y., Saiki, I., \& Kadota, S. (2002). Selective antiproliferative activity of caffeic acid phenethyl ester analogues on highly liver-metastatic murine colon 26-L5 carcinoma cell line. Bioorg. Med. Chem. 10:3351-3359. 
Li et al., Afr J Tradit Complement Altern Med., (2017) 14 (4): 213-220

https://doi.org/10.21010/ajtcam.v14i4.24

17. Patanasethanont, D., Nagai, J., Yumoto, R., Murakami, T., Sutthanut, K (2007). Effects of Kaempferia parviflora extracts and their flavone constituents on P-glycoprotein function. J Pharm Sci 96:223-233

18. Simon, H.U., Haj-Yehia, A., Levi-Schaffer, F., (2000). Role of reactive oxygen species (ROS) in apoptosis induction. Apoptosis, 5:415-418.

19. Staib, F., Hussain, S.P., Hofseth, L.J., Wang, X.W., Harris, C.C. (2003). TP53 and liver carcinogenesis. Hum Mutat. 21:201-216

20. Sun, S.Y., Hail, N., Jr Lotan, R., (2004). Apoptosis as a novel target for cancer chemoprevention. J. Natl. Cancer Inst. 96:662-672.

21. Takagaki, N., Sowa, Y., Oki, T., Nakanishi, R., Yogosawa, S., and Sakai, T. (2005). Apigenin induces cell cycle arrest and p21/WAF1 expression in a p53-independent pathway. Inter. J Oncol. 26: 185-190.

22. Tsuji, P. A., Winn, R. N., and Walle, T. (2006). Accumulation and metabolism of the anticancer flavonoid 5, 7 dimethoxyflavone compared to its unmethylated analog chrysin in the Atlantic killifish. Chemico-biol. Interact. 164:85-92.

23. Tsuji, P. A., Winn, R. N.,and Walle, T. (2006). Accumulation and metabolism of the anticancer flavonoid 5, 7dimethoxyflavone compared to its unmethylated analog chrysin in the Atlantic killifish. Chemico-biolo. Interac.164: $85-92$.

24. Urtreger, A. J., Ladeda, V. E., Puricelli, L. I., Rivelli, A., del Carmen Vidal, M., Sacerdote de Lustig, E., and Bal de Kier Joffé, E. D. (1997). Modulation of fibronectin expression and proteolytic activity associated with the invasive and metastatic phenotype in two new murine mammary tumor cell lines. Inter. J. Oncol., 11: 489-496.

25. Vermund, H., and Gollin, F. F. (1968). Mechanisms of action of radiotherapy and chemotherapeutic adjuvants: a review. Cancer, 21: 58-76.

26. Walle, T., Ta, N., Kawamori, T., Wen, X., Tsuji, P.A. (2007). Cancer chemopreventive properties of orally bioavailable flavonoids-methylated versus unmethylated flavones. Biochem Pharmacol. 73:1288-1296

27. Yang, J.F., Cao, J.G., Tian, L., Liu, F. (2012). 5, 7-Dimethoxyflavone sensitizes TRAIL-induced apoptosis through DR5 upregulation in hepatocellular carcinoma cells. Cancer chemother pharmacol. 69:195-206.

28. Yoneda, K., Yamamoto, T., Osaki T., (1998). p53- and p21-independent apoptosis of squamous cell carcinoma cells induced by 5-fluorouracil and radiation. Oral Oncol. 34:529-537.

29. Zou, W., Liu X, Yue P, Zhou Z, Sporn MB, Lotan R, Khuri FR, Sun SY. c-Jun NH2-terminal kinase-mediated upregulation of death receptor 5 contributes to induction of apoptosis by the novel synthetic triterpenoid methyl-2-cyano3, 12-dioxooleana-1, 9-dien-28-oate in human lung cancer cells. Cancer Res. 64:7570-7578 36. 